\title{
Studenten strooien hete centen voor het volk* \\ Stedelijke identiteit en de geschiedenis van een omstreden herinnering in Leiden (1841-2016)
}

Peter Burger \& Bart van der Steen

TSEG $15(1): 66-88$
DOI: $10.1835^{2} /$ TSEG. 1015

\begin{abstract}
Legend has it that students in the Dutch university town of Leiden used to throw coins in the street for the less well-off citizens. Picking up the coins, these risked burning their fingers: the students had heated the coins in a skillet. This story is told as emblematic for the social and cultural differences dividing labourers and students, or, more generally, 'town and gown'. Opinions differ about the veracity of the story and the time period during which this prank was perpetrated. Our study of this local legend is based on local newspapers and other digitized sources that have recently become available, allowing us to trace the story over a time period that spans the years 1841-2016. The hot coins prank is related to a more benign, internationally known custom during which both throwers and throwees know what to expect. In the Netherlands, stories about the prank have become associated in particular with the town of Leiden, becoming more prominent during the twentieth century, after the prank itself was no longer performed. We read the hot coin legend in the context of collective memory and urban identity: over the course of two centuries, various social groups have used the story as a boundary marker between in-group and out-group, and more broadly as a means to reflect on the shifting identity of the town. During the years of urban renewal in the second half of the twentieth century, Leiden transformed from an old, poor, industrial town into a modern, affluent urban centre that touts itself as a 'city of knowledge'. Rhetorically, the hot coin legend is presented as a test case for social cohesion: did Leiden truly leave behind its divided history?
\end{abstract}

\footnotetext{
* We zijn Jaap Moes, Pieter Slaman en Jasper van der Steen zeer erkentelijk voor hun suggesties en commentaar op eerdere versies van dit artikel.
} 
In Leiden gaat tot op heden een verhaal rond over een gebruik dat beschouwd wordt als sprekend voor de identiteit van de stad: corpsstudenten zouden in het verleden regelmatig gloeiende munten op straat hebben gegooid. Onwetende kinderen en arme Leidenaren zouden daarop, bij het oprapen van de munten, hun handen hebben gebrand. Het verhaal wordt gezien als kenmerkend voor de grote sociale en culturele verschillen in de stad, die volgens sommigen nog steeds bestaan.

Tijdens een symposium over de identiteit van de stad in 2008 haalde de antropologe Rivke Jaffe het verhaal over de gloeiende munten aan als typerend voor de Leidse identiteit. ${ }^{1}$ Veel zelfverklaarde 'echte' Leidenaren verwijzen regelmatig naar het gebruik. Toch komt het verhaal niet voor in de vele geschiedenissen van het studentencorps, ${ }^{2}$ noch in overzichtswerken over de geschiedenis van de stad. ${ }^{3}$ Ook in de huidige stadsmarketing, die dankbaar gebruik maakt van de roemruchte geschiedenis van Leiden als universiteitsstad, is geen plaats voor de hete centen. ${ }^{4}$

Ondergetekenden hoorden het verhaal over het munten strooien in het eerste jaar van hun studie (in 1979-1980, respectievelijk 200o2001), toen het gebruik al lange tijd tot het verleden behoorde. ${ }^{5}$ Dit roept de vraag op: waarom heeft dit verhaal in Leiden, na het uitsterven van het gebruik, nog zo lang een rol gespeeld in de stad en in discussies over de stedelijke identiteit?

Om deze vraag te beantwoorden, hebben we Leidse kranten doorzocht op beschrijvingen van en herinneringen aan het munten strooien. Regelmatig komen daarin stadsbewoners aan het woord die de handeling aanhalen, ofwel als persoonlijke herinnering dan wel in meer algemene zin. Doorgaans beschrijven ze niet alleen het gebruik, maar leveren ze ook een duiding, zodat het gerechtvaardigd is om te spreken over een retorische toop: een welbekende anekdote die feitelijk dient om een ander punt te ondersteunen. Op het eerste gezicht diende de anekdote om te reflecteren op de positie van de student in de stad. Afhankelijk van een positieve of negatieve inschatting daarvan werd de anekdote door

1 'Échte Leidenaar alleen dankzij de universiteit', Leidsch Dagblad, 1 oktober 2008.

2 L.D. Frank en H.B. Wiardi Beckman, Geschiedenis van het Leidsche Studentencorps (Leiden 1927);

H.G. van Duyl et al., Gedenkboek van het Leidsche Studentencorps (Leiden 1939); J.P. Naeff et al. (eds.), Geschiedboek van het Leidsche Studenten Corps (Leiden 1950); P. Bloem et al. (eds.), Mixtamorfose (Leiden 1975); S.G. Morsink e.a. (eds.), Geschiedboekvan de Leidse Studenten Vereniging Minerva (z.p. 1989); P. Sigmond en D. Meursink (eds.), Minerva voor het leven (Leiden 2014).

3 R.C.J. van Maanen en J.C.H. Blom (eds.), Leiden. De geschiedenis van een Hollandse stad. Leiden vanaf 1896 (Leiden 2004); C. Smit e.a., Het Leiden boek (Zwolle 2014).

4 Dezielvan Leiden (Leiden 2017).

5 P. Burger, De gebraden baby. Sagen en geruchten uit het moderne leven (Amsterdam 1995) 156. 
vertellers als waar of onwaar beschouwd en in een contemporain of ver verleden geplaatst. Maar de anekdote diende ook om te reflecteren op de staat van de stad. De anekdote stond daarbij symbool voor Leiden als oude, arme en verdeelde industriestad en riep de vraag op of Leiden zijn achtergestelde positie inmiddels overwonnen had.

Conceptueel gezien sluit ons artikel aan op discussies over collectief geheugen en stedelijke identiteit. Uitgangspunt is daarbij dat conflicten over het eigentijdse zelfbeeld ook de blik op het verleden beïnvloeden, waardoor beide veranderlijk zijn en met elkaar verbonden. De geschiedenis van het verhaal over de gloeiende munten toont dat nog eens extra duidelijk. Het collectieve en veranderlijke karakter van individuele herinneringen is aangetoond door Oral Historians als Portelli en Leydesdorf. ${ }^{6}$ De laatste liet zien hoe overlevenden van de Zeeuwse Watersnoodramp van 1953 in de jaren negentig populaire verhalen vertelden als hun eigen herinnering en gebeurtenissen uit de bezettingsjaren verbonden (en vermengden) met herinneringen aan de watersnoodramp.

Het verband tussen geheugen en geschiedenis is gethematiseerd door Assmann, ${ }^{7}$ die een onderscheid maakt tussen cultureel geheugen en communicatief geheugen. De eerste term duidt op het geheel van historische documenten dat een samenleving bewaart in archieven en bibliotheken, terwijl de laatste term verwijst naar dat deel van de geschiedenis dat mensen als parate kennis met zich meedragen. Door in kranten en andere publicaties op zoek te gaan naar vertellers die herinneringen ophalen aan het munten strooien, bevindt ons onderzoek zich tussen deze twee velden. Door de opkomst van memory studies zijn historici zich meer bezig gaan houden met verhalen zoals het onze, omdat zij een belangrijke bron vormen voor de reconstructie van het zelfbeeld van mensen en groepen.

Vaak gaat het daarbij om 'gekoesterde kwetsuren', herinneringen aan al dan niet daadwerkelijk geleden onrecht. Pattynama onderzocht de herinnering van Indonesiërs aan borden die tijdens de kolo-

6 A. Portelli, The death of Luigi Trastulli and other stories: Form and meaning in oral history (Albany, NY 1991); S. Leydesdorf, Het water en de herinnering. De Zeeuwse Watersnoodramp (1953-1993) (Amsterdam 1994).

7 J. Assmann, 'Communicative and cultural memory', in: A. Erll en A. Nünning (eds.), A companion to cultural memory studies. An international and interdisciplinary handbook (Berlijn en New York 2008) 109-118. Zie ook: A. Erll en A. Nünning, A companion to cultural memory studies; J.K. Olick en J. Robbins, 'Memory studies. From "collective memory” to the historical sociology of mnemonic practices', Annual Review of Sociology 24 (1998) 105-140; J.K. Olick, V. Vinitzky-Seroussi en D. Levy, 'Introduction', in: J.K. Olick en J. Robbins, The collective memory reader (New York 2011) 3-62. 
Illustratie 1 Collage van krantenknipsels (bron: Delpher).
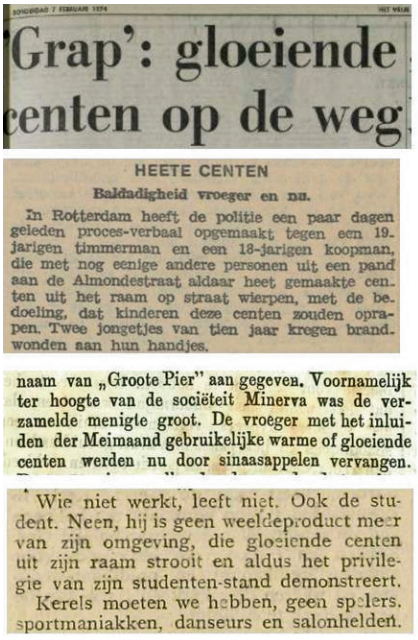

Flinke boete voor rare streek

Leids student wierp heet gemaakte centen naar kinderen

niet heilig verklaren. Maar ik wil evenmin dat die jongens steeds maar worden aangezien voor gemenerikken die gloeiende centen op straat werpen. Want wie dat praatje ooit in de wereld heeft ge. bracht.

Fokker ontkende net dat 'som. mige kwalijke elementen sic soms misdragen. Het bestuurslid van Minerva distantierde zich niet alleen van gloeiende centen die in vroeger jaren vanuit de koetsen naar de Leidse bevolkin werden geworpen maar zette zic daag de dag nog den die van. zijn dat, volgens Foorkomen al deringen. "Als ik leden zie die zich misdragen, vind ik dat net $z$ erg als iedereen, maar die rotte appels zullen er altijd zijn".

niale periode bij openbare zwembaden stonden met de tekst 'verboden voor honden en inlanders. ${ }^{8}$ Ondanks uitgebreid onderzoek bestaan er (nog) geen bewijzen dat deze borden daadwerkelijk naast de zwembaden hebben gestaan, maar ze maken desondanks een belangrijk onderdeel uit van de herinnering van Indonesiërs aan de koloniale periode. Op eenzelfde manier onderzochten Somers en Van Poppel het verhaal dat priesters vroeger langs de deuren gingen bij katholieke gezinnen om hen aan te zetten meer kinderen te krijgen. ${ }^{9}$ In deze twee onderzoeken ligt de nadruk vooral op het waarheidsgehalte van de verhalen. Wij willen echter onderzoeken hoe het munten strooien zich heeft ontwikkeld van een algemeen folkloristisch gebruik tot een 'typisch' Leidse herinnering.

Het verhaal over de gloeiende munten is veel verteld, maar speelt vrijwel geen rol in de geschiedschrijving over de stad. Deze bijdrage reageert op deze lacune in de literatuur. Nadat de ontwikkeling van het gebruik is geschetst, wordt de ontwikkeling van het verhaal gereconstrueerd en vervolgens geanalyseerd hoe verschillende groepen (corpsstudenten, 'echte' Leidenaren en betrokken burgers) zich tot het verhaal verhielden om te verklaren waarom het nog zo lang een prominente rol heeft gespeeld in het zelfbeeld van veel Leidenaren.

8 P. Pattynama, 'Cultural memory and Indo-Dutch identity formations', in: U. Bosma (ed.), Post-Colonial immigrants and identity formations in the Netherlands (Amsterdam 2012) 175-192.

9 A.Somers en F. van Poppel, 'Priest, parishioner and posterity. A Dutch urban legend or historical fact?', The History of the Family 15 (2010) 174-19o. 


\section{Gedigitaliseerde kranten als historische bron}

De Leidse dagbladen uit de negentiende en twintigste eeuw bieden een uitgelezen bron om deze ontwikkeling te reconstrueren. We hebben ons materiaal aangevuld met andere bronnen, waaronder gedigitaliseerde landelijke en regionale kranten, studentenalmanakken en literaire teksten. ${ }^{10}$

Gedigitaliseerde kranten vormen een seriële bron, die in zijn geheel doorzien en systematisch doorzocht kan worden. Deze bron leent zich het beste voor het beantwoorden van onze vragen. Interviews met Leidenaren geven weliswaar inzicht in hoe individuele stadsbewoners het gebruik nú herinneren en duiden, maar stellen ons niet in staat de verandering van deze duiding door de tijd heen te reconstrueren. Politie- en rechtbankverslagen bieden slechts zeer selectief inzicht in de ontwikkeling van het gebruik, omdat het munten strooien tot aan het einde van de negentiende eeuw slechts zelden leidde tot juridisch ingrijpen.

We hebben ons dus gewend tot contemporaine verslagen en herinneringen, vastgelegd in kranten, vanaf de vroegste vermelding van het gebruik in 1841 tot op heden. In veel gevallen gaat het om krantenbijdragen waarin redacteurs anekdotes opdissen, persoonlijke herinneringen delen of interviews afnemen waarin anderen het gebruik noemen.

De materiaalverzameling voor dit artikel, afgesloten in mei 2016, leverde uiteindelijk een corpus op van 162 Nederlandstalige teksten uit de jaren 1841-2016 (tabel 1). Hiervan gaan er 13 over het strooien van munten buiten Nederland. Van de overige 149 bronnen gaan er 5 o over strooien met gloeiende munten in Leiden (1841-2016); 5 over strooien met onverhitte munten in Leiden (186o-1940); 38 over gloeiende munten elders in Nederland (1846-2015); en 56 over het strooien van niet-verhitte munten elders in Nederland (1844-2016) (tabel 2). Bij de selectie hebben we ernaar gestreefd zo veel mogelijk verschillende meldingen en meningen over het strooien met verhitte en onverhitte munten te vinden. We hebben niet gepoogd om alle afzonderlijke publicaties hierover op te nemen: krantenartikelen die in meer kranten werden afgedrukt, zijn slechts een keer opgenomen.

10 Naast Delpher, Leiden.courant.nu en LexisNexis hebben we vooral gebruik gemaakt van de Digitale Bibliotheek der Nederlandse Letteren (DBNL), Google Books, studentenalmanakken, blogs en forumdiscussies. De drie Leidse dagbladen zijn het Leidsch Dagblad (186o-heden), de Leids(ch)e Courant (16881992) en de Nieuwe Leidsche Courant (1920-1980). Steekproefsgewijs hebben we Google News Archive, Chronicling America en Proquest Historical Newspapers geraadpleegd. 
Wanneer we de meldingen uitsplitsen over decennia (tabel 2), worden enige trends zichtbaar. In de eerste plaats blijkt dat het strooien van hete munten ook in andere Nederlandse plaatsen werd gesitueerd, maar tegelijkertijd disproportioneel vaak geassocieerd werd met Leiden: meer dan de helft van de berichten over hete munten ( 5 o van de 88 ) gaat over de Sleutelstad. Bovendien: wanneer berichten na 1940 Leiden en munten strooien in een adem noemen, gaat het altijd om verhitte munten. We zien hier de ontwikkeling van het verhaal tot een Leidse toop.

Tabel 1 Gebruikte Nederlandstalige teksten over het strooien van munten, verdeeld naar decennium en herkomst

\begin{tabular}{|c|c|c|c|c|c|}
\hline Decennium & Totaal & $\begin{array}{l}\text { Leidse } \\
\text { kranten }\end{array}$ & $\begin{array}{l}\text { Andere } \\
\text { Leidse } \\
\text { bronnen }\end{array}$ & $\begin{array}{c}\text { Andere } \\
\text { Nederlandse } \\
\text { kranten }\end{array}$ & $\begin{array}{c}\text { Andere } \\
\text { Nederlandse } \\
\text { bronnen }\end{array}$ \\
\hline 1840 & 4 & 0 & 1 & 1 & 2 \\
\hline 1850 & 2 & 0 & 1 & 0 & 1 \\
\hline 1860 & 6 & 0 & 1 & 1 & 3 \\
\hline 1870 & 5 & 0 & 0 & 1 & 4 \\
\hline 1880 & 12 & 2 & 0 & 8 & 2 \\
\hline 1890 & 10 & 0 & 0 & 8 & 2 \\
\hline 1900 & 5 & 0 & 0 & 4 & 1 \\
\hline 1910 & 16 & 1 & 0 & 13 & 2 \\
\hline 1920 & 13 & 2 & 0 & 7 & 4 \\
\hline 1930 & 20 & 2 & 0 & 15 & 3 \\
\hline 1940 & 1 & 1 & 0 & 1 & 0 \\
\hline 1950 & 4 & 0 & 1 & 3 & 0 \\
\hline 1960 & 7 & 5 & 0 & 1 & 1 \\
\hline 1970 & 12 & 4 & 1 & 5 & 2 \\
\hline 1980 & 13 & 6 & 2 & 2 & 3 \\
\hline 1990 & 10 & 2 & 2 & 5 & 1 \\
\hline 2000 & 7 & 3 & 1 & 0 & 3 \\
\hline 2010 & 15 & 1 & 3 & 4 & 6 \\
\hline Totaal & 162 & 29 & 13 & 79 & 40 \\
\hline
\end{tabular}

Zie voetnoot 10 voor de gebruikte bronnen. 
Tabel 2 Verwijzingen naar het strooien van munten in onze bronnen, geordend op uitvoering en locatie (verhit of niet, gesitueerd in Leiden of elders in het land)

\begin{tabular}{|c|c|c|c|c|}
\hline Decennium & $\begin{array}{l}\text { Hete munten in } \\
\text { Leiden }\end{array}$ & $\begin{array}{l}\text { Hete munten } \\
\text { elders in } \\
\text { Nederland }\end{array}$ & $\begin{array}{c}\text { Onverhitte } \\
\text { munten in Leiden }\end{array}$ & $\begin{array}{c}\text { Onverhitte } \\
\text { munten elders in } \\
\text { Nederland }\end{array}$ \\
\hline 1840 & 1 & 1 & 0 & 2 \\
\hline 1850 & 0 & 0 & 0 & 2 \\
\hline 1860 & 0 & 0 & 1 & 2 \\
\hline 1870 & 0 & 1 & 0 & 4 \\
\hline 1880 & 4 & 2 & 0 & 4 \\
\hline 1890 & 1 & 0 & 2 & 7 \\
\hline 1900 & 0 & 0 & 0 & 4 \\
\hline 1910 & 1 & 4 & 0 & 11 \\
\hline 1920 & 2 & 4 & 1 & 3 \\
\hline 1930 & 1 & 9 & 0 & 9 \\
\hline 1940 & 0 & 0 & 1 & 0 \\
\hline 1950 & 0 & 1 & 0 & 1 \\
\hline 1960 & 5 & 0 & 0 & 2 \\
\hline 1970 & 6 & 5 & 0 & 0 \\
\hline 1980 & 9 & 1 & 0 & 3 \\
\hline 1990 & 5 & 5 & 0 & 0 \\
\hline 2000 & 5 & 2 & 0 & 0 \\
\hline 2010 & 10 & 3 & 0 & 2 \\
\hline Totaal & 50 & 38 & 5 & 56 \\
\hline
\end{tabular}

Verwijzingen naar het strooien van munten in het buitenland zijn niet opgenomen. Zie voetnoot 10 voor de gebruikte bronnen.

Daarnaast kunnen we drie periodes herkennen waarin het strooien van munten vaker besproken werd: de laatste twee decennia van de negentiende eeuw, de periode 1910-1940 en de periode 1960-200o. Tegelijkertijd zijn de aantallen per decennium zo laag, dat men op moet passen met al te stellige gevolgtrekkingen.

Er zitten enkele methodologische haken en ogen aan gedigitaliseerde kranten als historische bron, enerzijds veroorzaakt door de aard van kranten an sich en anderzijds door de opzet van de digitale archieven. ${ }^{11}$

11 M. Broersma, 'Nooit meer bladeren? Digitale krantenarchieven als bron', Tijdschrift voor Mediageschiedenis 14 (2011) 29-55; M. van den Bos en H. Giffard, 'The grapevine. Measuring the influence of 
Kranten vormen geen neutrale bron van feitelijke informatie: zowel hun commerciële als hun wereldbeschouwelijke karakter bepalen de nieuwsselectie en kleuren de berichtgeving. Bovendien schrijven kranten over incidenten, over gebeurtenissen die ongebruikelijk, schokkend of controversieel zijn. Het alledaagse speelt in kranten slechts een kleine rol.

Nieuws is dan ook niet zozeer een afspiegeling van belangrijke gebeurtenissen, maar een constructie, die de sociale werkelijkheid mede schept, door te stipuleren wat belangrijk is. Lokale nieuwsmedia rapporteren actuele incidenten - zoals een student die hete munten naar kinderen gooit - en evalueren ze ('een rare studentenstreek'), maar ze leggen ook herinneringen vast van stadsbewoners en dragen zo bij aan de vorming van het collectieve geheugen van de stad. ${ }^{12}$ Aan de ene kant reflecteren kranten het collectieve geheugen, wanneer zij alom bekende 'weetjes' als feiten publiceren. Aan de andere kant sturen ze het collectieve geheugen, omdat mensen voor hun kennis over hun omgeving voor een groot deel uit deze media putten. ${ }^{13}$

Bij het werken met gedigitaliseerde kranten komen er nog een aantal andere zaken om de hoek kijken. Zoeken op steekwoord kan tot vertekeningen leiden wanneer men zich te weinig rekenschap geeft van context en mogelijke betekenisverandering. Daarom is niet alleen gezocht op gloeiende munten, maar ook op dito centen, duiten en stuivers. Daarbij zijn de munten niet alleen gloeiend, maar ook heet, verhit, witheet enzovoort. Tegelijkertijd kan zo'n manier van zoeken nog altijd tot vertekeningen leiden, wanneer men zich niet bewust is van het feit dat er vaak niet alleen met munten, maar ook met sigaren, sinaasappels en snoepgoed werd gestrooid (waarvan dikwijls de spelling varieerde). Het is, kortom, zaak om niet alleen 'breed' te zoeken (middels verschillende zoektermen), maar ook 'contextueel' te zoeken (dus niet alleen op munten).

Dutch newspapers on Delpher', Tijdschrift voor Tijdschriftstudies 38 (2015) 29-41; K. van Krieken, 'Using digital archives in quantitative discourse studies. Methodological reflections', Tijdschrift voor Tijdschriftstudies 38 (2015) 43-50.

12 B. Zelizer, 'Why memory's work on journalism does not reflect journalism's work on memory', Memory Studies 1:1 (2008) 79-87; B. Zelizer en K. Tenenboim-Weinblatt (eds.), Journalism and memory (Houndmills, Basingstoke 2014).

13 C. Kitch, 'Placing journalism inside memory - and memory studies', Memory Studies 1:1 (2008) 311320 . 
Ten slotte dekt Delpher, de grootste digitale krantenbank in het Nederlandse taalgebied, de afgelopen vier eeuwen niet volledig. De opgenomen kranten zijn niet alleen geselecteerd op basis van oplage en copyrightkwesties, maar de samenstellers hebben ook gestreefd naar een zo breed mogelijk palet aan politieke en wereldbeschouwelijke stromingen. Dit roept vragen op over de representativiteit: namens wie sprak een bepaalde krant en welke c.q. hoeveel mensen lazen hem? Bovendien groeit Delpher nog altijd, zodat we hier niet te maken hebben met een duidelijk afgebakend corpus aan bronnen - wat wederom implicaties heeft voor de representativiteit van de bron. In april 2016 werden aan Delpher ongeveer drie miljoen nieuwe krantenpagina's toegevoegd. Hierdoor steeg het aantal - nog niet op relevantie beoordeelde - treffers voor heete centen, een van onze zoektermen, van 940 naar $1420 .{ }^{14}$ Dat laatste speelt bij de Leidse krantendatabase geen rol, aangezien deze er aanspraak op maakt alle drie de Leidse dagbladen uit de negentiende en twintigste eeuw volledig te hebben gedigitaliseerd.

\section{Van praktijk tot verhaal}

\section{Het 'ware'verhaal}

Hebben Leidse studenten ooit hete munten gegooid naar 'het volk'? Ja, dat hebben ze, maar van oorsprong was het gebruik niet typisch Leids (of zelfs maar Nederlands), noch was het bij uitstek een studentenstreek. Strooien met hete munten was deel van een oudere en veel bredere folkloristische traditie. Bij bruiloften, meifeesten en intochten werden tot aan het einde van de negentiende eeuw regelmatig hete munten gestrooid. Voor zover het gebruik Leids en studentikoos was, stierf het eind negentiende eeuw grotendeels uit, hoewel er incidenten bekend zijn uit het interbellum en zelfs eenmaal in 1961.

Strooien met hete centen was een variatie op het 'te grabbel' gooien van muntgeld voor kinderen, armen en onderdanen. Vorsten lieten ter gelegenheid van hun inhuldiging speciale 'strooipenningen' slaan, een gebruik dat in Nederland standhield tot het einde van de negentiende eeuw. ${ }^{15}$ Het rondstrooien van munten was rond het mid-

14 'Drie miljoen nieuwe pagina's', Delpher Nieuwsbrief, 13 april 2016. Cijfers over treffers op basis van zoekactie op 22 april 2016.

15 E. Elzenga, De inhuldigingen. Van Willem tot Beatrix (Amsterdam 2013) 143. 
den van de negentiende eeuw tevens een vast onderdeel van feestelijkheden, zoals lentefeesten en bruiloften. Maar ook buiten deze hoogtijdagen om lieten welgestelden kinderen of armen delen in hun rijkdom door hen een handvol munten toe te werpen.

Zowel bij feestelijkheden als bij het 'alledaagse' munten strooien kwam het voor dat de strooiers de munten hadden verhit. In Nederland was het gebruik aan het einde van de negentiende eeuw zo bekend, dat het aangehaald werd in een lemma van het woordenboek van Van Dale (1872, 'omstrooien'): 'De jongelui hebben gloeiende centen onder de straatjongens omgestrooid'.

Hete munten strooien was geen zuiver Nederlands gebruik, getuige bijvoorbeeld de 'Rye hot pennies', die de burgemeester van Rye in Sussex na zijn verkiezing traditioneel op het stadhuisplein zou hebben gegooid. Deze 'grabbelfolklore' is ook in andere Engelse plaatsen bekend, waarbij vaak plaatselijke ontstaansgeschiedenissen worden aangehaald - ondanks het feit dat het gebruik wijdverbreid was. ${ }^{16} \mathrm{Zo}$ zijn er meldingen bekend uit het nabijgelegen Oxford, maar ook uit Chili en de Verenigde Staten. ${ }^{17}$

Ook in Nederland zijn er verschillende lokale verhalen bekend over het munten strooien. Zo kende Sint Pieter te Gees (gemeente Coevorden) aan het begin van de negentiende eeuw de traditie van het 'balslaan'. Een keer per jaar trok de schooljeugd langs de huizen van jonggehuwden in het dorp, die met centen strooiden: 'Onder het grabbelen naar dezelven gebeurt het echter niet zelden, dat deze of gene volwassene zijne ruwe aardigheden bot viert, door de vrolijk grabbelende kleinen emmers vol water over het lijf te storten.' ${ }^{18}$

In andere gevallen kreeg het strooien van centen een grimmiger karakter, vooral wanneer er onverwachte elementen aan het 'spel' werden toegevoegd. Zo beschreef een ooggetuige een gebeurtenis aan het einde van negentiende eeuw, toen in Harderwijk geleger-

\footnotetext{
16 J. Simpson en S. Roud, Oxford dictionary of English folklore (Oxford 2000) 303. Zie ook: T.W. Carrick, 'Scraps of English folklore, XVIII. Cumberland', Folklore 40 (1929) 278-29o.

17 A. van den Breemer, 'Townies \& Gownies', de Volkskrant, 15 september 2012. Over Chili: 'Judaspoppen in de fik', op: http://www.samsam.net/judaspoppen-in-de-fik (opgeroepen 5 december 2016). In de vs leven herinneringen aan hete munten die met Halloween werden uitgedeeld aan trick-or-treaters: S. Grider, 'The razor blades in the apples syndrome', in: P. Smith (ed.), Perspectives on contemporary legend. Proceedings of the conference on contemporary legend, Sheffield, July 1982 (Sheffield 1984) 128140, aldaar 133-134.

18 J.van der Veen, Drentsch mozaïk, re stukje (Groningen 1844). Zie ook: J. ter Gouw, De volksvermaken (Haarlem 1871) 265; 'Sint Pieter Balslaan' op: http://www.encyclopediedrenthe.nl/Sint\%2oPieter\%2o balslaan (13 feb. 2016).
} 
de soldaten vanuit een herberg 'een veertig- of vijftigtal centen' naar zo'n vijftig kinderen gooiden, die zich er 'als honden' op stortten: 'Dan op eens worden van uit de hoogte een paar emmers water leeggestort met het gevolg, dat in een oogwenk de bende uiteenstuift.' 'Zulke tooneeltjes' vonden volgens de verteller 'schier overal' plaats. ${ }^{19}$ In dit geval ging het echter niet om een lokaal gebruik, maar om een dat met de soldaten meereisde. Het is daarom goed mogelijk dat het water een toevoeging was waar de grabbelaars niet op rekenden.

In Leiden werd van oudsher op jaarlijkse vieringen zoals het lentefeest en het Leids Ontzet ( 3 oktober) met munten gestrooid. Volgens de Nieuwe Hoornsche Courant van 1884 werd elk jaar op 30 april de fontein op de Leidse Vismarkt opnieuw in gebruik genomen met een ritueel waarbij bewoners van de huizen rondom gloeiende centen uit het raam gooien voor de 'lieve jeugd' bestaande uit 'straatjongens en fabriekers'. ${ }^{\circ}$

Rond dezelfde tijd waren ook studenten betrokken bij het munten strooien. In $185^{8}$ trokken Leidse studenten naar het platteland, waar zij centen naar 'de boeren en boerinnetjes' en hun kinderen strooiden en 'schaterden' om het 'worstelen om den buit.. ${ }^{21}$ Rond 1860 vond het gebruik ook plaats binnen de muren van de universiteitsstad. De jaarlijkse bijeenkomst van studenten van de sociëteiten Amicitia en Minerva ging standaard gepaard met het strooien van munten: 'In den namiddag verzamelt zich dan voor Minerva de gehele bevolking uit de achterbuurten, om hunne vingers te komen verschroeijen aan de heete centen, welke dan door de Muzenzonen met kwistige hand onder hen worden uitgestrooid. ${ }^{22}$ Toch leidde het gebruik toen al tot spanningen. In 186o werden studenten op straat door 'straatjongens' gevolgd, die bij hen bedelden om centen. Toen deze weigerden, scholden ze de studenten uit voor 'kale spoelhonden'. Een verbolgen student typeerde 'de Leidsche species van 't genus straatjongen' vervolgens als 'zeker wel de ellendigste, naarste, akeligste' van Nederland. ${ }^{23}$

19 De getuige was er echter niet van gecharmeerd: ' $\mathrm{Nu}$, ik ben later nooit weer met soldaten ... een herberg binnen gegaan'. Zie: 'Uit den Atjeh-tijd', Overveluwsch Weekblad/Harderwijkerkrant, 1 juli 1908.

20 'Een brief uit Leiden', Nieuwe Hoornsche Courant, 10 mei 1884. Zie over Leiden als laatste stad met een Meifeest ook: 'De meiboom', De Tijd, 30 april 1899.

21 Noord en Zuid: Akademische mengelingen uitgegeven door het taalminnend studenten-genootschap [...] te Brussel, met de medewerking van studenten aan de verschillige Hollandsche en Belgische hooge scholen. Tweede deel (Brussel 1858) 79 .

22 'Publieke vermakelijkheden in 186o', Leidsch Dagblad, 1 maart 196o.

23 Leidsche studenten-almanakvoor 1860 (Leiden 1860) 198-199. 


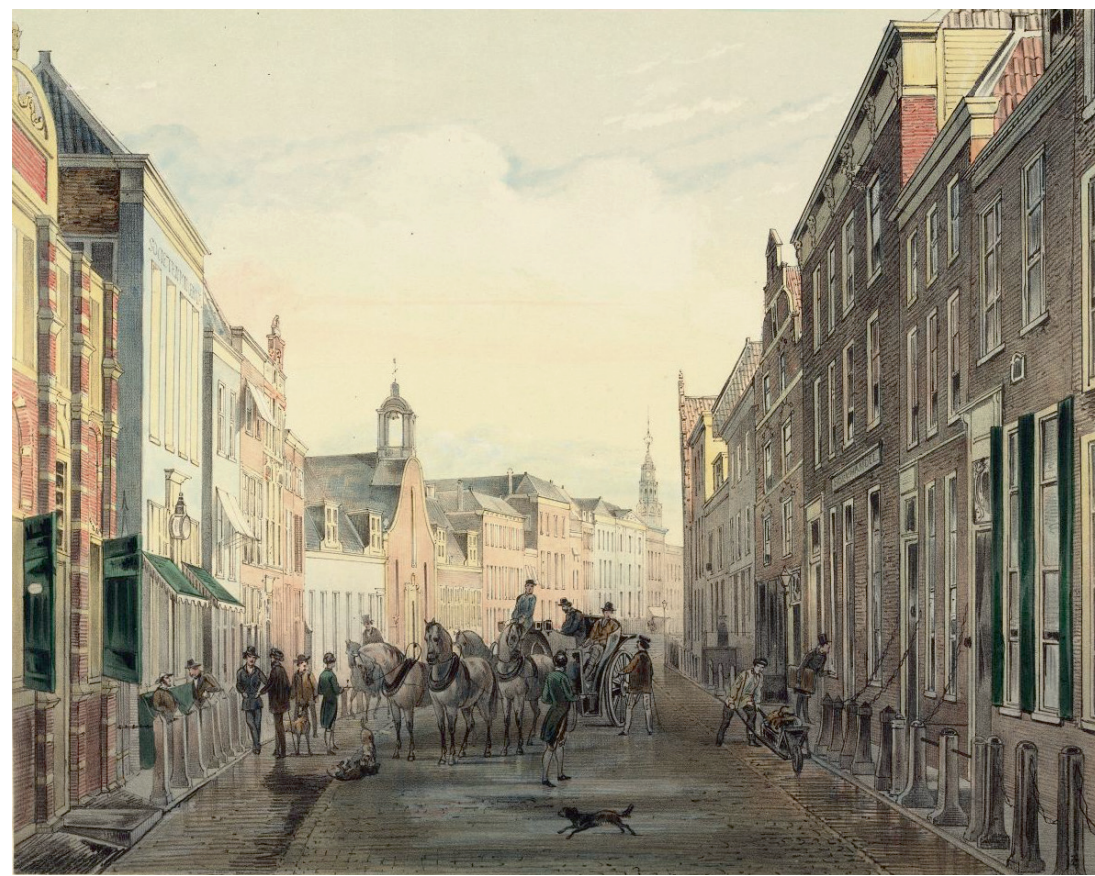

Illustratie 2 'Leyden'. De Breestraat bij Minerva. Ca. 1850, door Gerardus Johannes Bos (1825-1898) (bron: $h$ ttp://www.archiefleiden.nl/home/collecties/beeldmateriaal/).

Het gebruik om munten te strooien - ook onverhitte - raakte in de tweede helft van de negentiende eeuw omstreden. In de landelijke pers werd het gebruik vaker besproken. Aan het eind van de eeuw deden zich een aantal noemenswaardige incidenten voor. In Nijkerk brak een jongen in 1895 zijn been, toen hij viel bij het grabbelen naar 'eenige centen'. ${ }^{24}$ Een jaar later had er een veel tragischer ongeval plaats in Leiden. Toen de bestuurder van een bierwagen de Koornbeursbrug wilde afrijden, 'bemerkte hij aan de Vischmarkt het stilstaande rijtuig met heeren studenten, rondom waarvan vele menschen'. De studenten strooiden munten naar jonge kinderen. De bestuurder begon daarop 'te schreeuwen zoo hard hij kon ... doch dit scheen niet gehoord te worden, althans de lui bleven staan'. De bestuurder verloor vervolgens de controle over de wagen en reed een zevenjarig kind aan, dat hierdoor zwaar gewond raakte. 'Het kind werd onmiddellijk naar het politiebureel gedragen, waar het spoe- 
dig overleed'. ${ }^{25}$ Weer twee jaar later, in 1898 liet koningin Wilhelmina op scholen penningen uitdelen ter ere van haar inhuldiging. Bij de inhuldiging van Willem III in Amsterdam in 1849 was er op straat hard gevochten om gestrooide munten; dat wilde men dit keer voorkomen. ${ }^{26}$

Het is aannemelijk dat het gebruik rond de eeuwwisseling is uitgedoofd. In 188o kozen Minervastudenten er tijdens de Diesviering voor om het gooien van gloeiende munten achterwege te laten; de 'gebruikelijke warme of gloeiende centen werden nu door sinaasappelen vervangen,. ${ }^{27}$ In 1914 meldde de Sumatra Post dat het gebruik in Leiden 'zijn tijd heeft gehad'. ${ }^{28}$ In de jaren twintig werd het fenomeen nog wel genoemd, maar slechts in de verleden tijd. In 1930 stelde de Provinciale Overijsselsche en Zwolsche Courant dat het strooien van verhitte munten in Groningen sinds 1905 niet meer voorkwam. ${ }^{29}$ Ook vanuit Leiden waren er geen nieuwe berichten over het gebruik ontvangen: 'Wij weten niet, of er in Leiden ook nu nog op 3 October heete centen worden gestrooid. ${ }^{\circ}$

Volgens sommigen leefde het gebruik tot in het interbellum voort. ${ }^{31}$ Het is mogelijk dat het in deze periode incidenteel nog voorkwam, maar het is zeer onwaarschijnlijk dat het toen nog regelmatig gebeurde. Opvallend is dan ook dat de variatie in de beschrijving van het gebruik steeds groter wordt, naarmate het verder in de twintigste eeuw wordt geplaatst.

25 'Leiden, 9 november', Leidsch Dagblad, 10 november 1896; 'Gemengd nieuws', Leidsch Dagblad, 11 november 1896 . Volgens de Schoonhovense Courant ging het om een vijfjarig jongetje dat zich niet op tijd uit de voeten kon maken 'zoodat de bierwagen over den armen knaap heenging en hem letterlijk de borstkas verbrijzelde'. De jongen stierf ter plekke. Schoonhovensche Courant, 11 november 1896.

26 P. Jonas, Neêrlands koning in Neêrlands hoofdstad. Eene herinnering aan 11 en 12 mei 1849 (Amsterdam 1849) 53; D. van der Meulen, Koning Willem III, 181 7-1 89o (Amsterdam 2013) 223.

27 'Leiden, 9 februari', Leidsch Dagblad, 10 februari 188 o.

28 'Uit de Hofstad', Sumatra Post, 6 februari 1914.

29 'Heete centen: Baldigheid vroeger en nu', Provinciale Overijsselsche en Zwolsche Courant, 5 mei 1930. Zie ook Nieuwsblad van het Noorden, 23 december 1922: 'Voor omstreeks 13 o jaar zag een winkelier dat eenige dronken heeren zich vermaakten door voor hun clubgebouw eenige gloeiende centen onder een troep jongens te gooien'.

30 'Heete centen. Baldigheid vroeger en nu', Provinciale Overijsselsche en Zwolsche Courant, 5 mei 1930. 31 'Toen de tv kwam, was de gezelligheid voorbij', Leidsch Dagblad, 7 april 1984. Zie ook: 'Pleidooi voor woede', De Waarheid, 2 oktober 1984; 'Corpsballen', Het Vrije Volk, 2 maart 1977. Volgens een verteller vond het munten strooien zelfs tot in de jaren vijftig plaats: 'Het volk versus de student', Mare, 21 september 2006 . 


\section{Het verhaalverteld}

Al voordat het gebruik van munten strooien door studenten uitstierf, werd het verhaal erover gebruikt om mensen te typeren, gedrag af te keuren en bepaalde waarden te huldigen. Het verhaal ontwikkelde zich tot een retorische toop die regelmatig werd aangehaald in nieuwsberichten, maar ook in persoonlijke verslagen, verhalen en romans. De oudste en bekendste vermelding stamt uit Studentenschetsen (1841) van de student-auteur Klikspaan (pseudoniem van Johannes Kneppelhout). In dit boek komt de student Flanor voor, van wie wordt gezegd:

Flanor was het die op den derden October de meeste en heetste centen uit het raam gooide op de deftige Leidsche wandelaars, die dan door gretige kleine straatjongens bestormd en omvergehaald werden en, Gullivers in handen van Lilliputters, dachten om te komen onder de worsteling welke om, over en op hen geleverd werd, terwijl de onvermoeibare Studiosus, bijgestaan door onvermoeibare vrienden, steeds meer gloeijende centen naar beneden liet regenen, hetgeen steeds meer gehuil, gevecht, getrap, gekrab en bloedneuzen onder de lieve Leidsche jeugd te weeg bragt. ${ }^{32}$

Tussen de types die Klikspaan opvoert, is Flanor de ideale student: de gulle, brutale gangmaker van de groep. Dat hij de straatjongens laat vechten om zijn hete centen en zo de 'deftige Leidsche wandelaars' te grazen neemt, is voor de schrijver een voorbeeld van studentikoze levenskunst.

Dat het gebruik echter - niet alleen de practical joke met hete centen, ook munten strooien in het algemeen - ook toen al op afkeuring stuitte, blijkt uit een kinderboek dat nog geen vier jaar later verscheen. In Willem Essensteyn (1845) geeft een vader zijn drie kinderen elk vijf gulden. Een van de drie, Jan, wisselt de guldens om in kleine munten, die hij op straat gooit om te zien hoe arme kinderen erom vechten. De vechtpartijen geven Jan veel plezier, maar zijn vader keurt Jans gedrag streng af. ${ }^{33}$

Deze kritiek neemt toe in de tweede helft van de negentiende eeuw, maar studenten zelf zagen er lange tijd geen kwaad in. In een feuilleton uit de jaren 1880 komt een baldadige groep Leidse jongeren voor, onder wie een jongeheer 'die het volgend jaar, als het staatsexamen niet weder ingesteld wordt, hoopt student te worden'. Hij 'stelt voor, om gloeiende centen uit te strooien', maar de rest verkiest het om snoepgoed naar de

32 Klikspaan, Studentenschetsen. Studieuitgave, bezorgd door A. Kets e.a. Deel 1: Teksten (Den Haag 2002) 159 .

33 Willem Essensteyn. Een aangenaam verhaal van zijne goede daden en gelukkige tevredenheid (Leiden 1845). 
kinderen te strooien. ${ }^{34}$ Het gebruik was kennelijk onder de jongeren zijn aantrekkingskracht aan het verliezen.

Kritiek werd ook in reactie op daadwerkelijke praktijken geuit. Zo bekritiseerde ene 'Casacara' in 1885 in een uitgebreid stuk de heer Waring uit Vlissingen, die zijn meid 'elken eerste Zaterdag van de maand' centen liet strooien voor de armen, die bij het grabbelen leken op 'een troep kippen'. Het gebruik was volgens Casacara denigrerend en beledigend. ${ }^{35} \mathrm{Na}$ de eeuwwisseling werd het munten strooien steeds zeldzamer en wanneer het gebeurde, leidde dat telkens tot politieoptreden. Hoe minder het gebruik voorkwam, hoe heviger de reacties in de pers werden. Toen twee jongemannen in 1930 in Rotterdam gloeiende munten hadden gestrooid, waarna kinderen brandblaren hadden opgelopen, reageerden verschillende journalisten en brievenschrijvers met verontwaardiging. 'Je zoudt ze ten minste met een paar druppels kokende olie willen bewerken', stelde een schrijver. ${ }^{36}$ Een ander stelde: 'Wij meenen, dat de rechter in uitzonderingsgevallen het recht zou moeten hebben om bepaalden veroordeelden een pak slaag te doen geven.' ${ }^{37}$

\section{Een 'typisch' Leids gebruik: veranderende betekenis}

\section{Jaren twintig: de student als deel van het volk}

In de twintigste eeuw kwam het munten strooien nog maar zelden voor. Des te meer werd er echter over gesproken, waarbij het verhaal telkens een nieuwe lading kreeg. Als anekdote werd het een middel om te reflecteren op de rol van de student in de stad en op de staat van de stad zelf. Dat gebeurde met name in de periode van 196o tot het begin van de jaren negentig en in mindere mate ook in de jaren twintig.

In de jaren twintig haalden zowel Leidse sociaaldemocraten als conservatieven het verhaal aan om hun eigen beweging aan te prijzen. Tegenover de oude verhoudingen, waarin de student tegenover de werkende bevolking stond, plaatsten zij hun eigen beweging, waarin deze tegenstelling was overwonnen ten bate van een nieuw maatschappijbeeld, waarin beide groepen harmonieus naast elkaar zouden bestaan.

Zo haalden sociaaldemocraten in 1924 het voorbeeld aan van studenten die 'eertijds' gloeiend gemaakte centen naar het proletariaat

\footnotetext{
34 'Feuilleton. Eene variatie op een oud lied', Het Nieuws van den dag, 5 december 1882.

35 Casacara, 'Een praatje over Maskerade II', Vlissingsche Courant, 5 maart 1885.

36 'Onder het zoeklicht', De Tijd, 29 april 193 o.

37 Provinciale Geldersche en Nijmeegsche courant, 3 mei 1930.
} 
gooiden, 'terwijl velen hunner thans welbewust de vaan der bevrijding volgen..$^{38}$ Ook conservatieve studenten spraken in 1925 over het centen strooien door studenten, om vervolgens te betogen dat de laatsten inmiddels een deel waren geworden van de natie: 'Hollanders zijn werkers[,] van den professor, tot den koopman, van den boer tot den wever. [De student] is geen weeldeproduct meer van zijn omgeving, die gloeiende centen uit zijn raam strooit en aldus het privilegie van zijn studenten-stand demonstreert.' ${ }^{39}$

Dat de historische waarheid in deze anekdote ondergeschikt was aan de boodschap die ermee verteld werd, blijkt uit de terloopse melding van het gebruik, dat niet verder werd toegelicht. In beide vertogen werd het centen strooien geplaatst in een onbestemd 'vroeger', werd er geen melding meer gemaakt van het gooien van sinaasappels en sigaren naast de munten of het gooien van water over de grabbelende kinderen. Uit de vluchtige vermelding blijkt tevens dat de auteurs ervan uitgingen dat de lezer het verhaal al kende.

Tegelijkertijd riepen de stellige beweringen van de sociaaldemocraten en conservatieven ook een spanning op: was de wens hier vader van de gedachte? Rond de eeuwwisseling was de rol van de student in de stad een belangrijk thema geweest. Via het Toynbeewerk probeerden studenten een bijdrage te leveren aan de verheffing van het volk en in 1905 en 1910 organiseerden zij grote historische optochten door de stad (maskerades) als geste om hun verbondenheid met de stad te benadrukken..$^{40} \mathrm{Na} 1910$ waren deze inspanningen echter op een lager peil komen te staan. De economische crisis van de jaren dertig deed de sociale tegenstellingen in de stad vervolgens weer toenemen. Volgens de journaliste Friederike de Raat, terugblikkend in 1996, was Leiden lange tijd een 'stad met twee gezichten', waarbij de tweedeling zich ook geografisch openbaarde: 'Het noorden en oosten van de binnenstad was overwegend eenvoudig en werd grotendeels bewoond door arbeiders en ambachtslieden. Het monumentalere zuiden werd gedomineerd door de universitaire elite rond het Rapenburg. De Rijn vormde de scheiding. ${ }^{\prime 4}$

38 'Vijf-en-twintig-jarig bestaan van de afdeeling Leiden der SDAP', Leidsch Dagblad, 2 juni 1924.

39 'Groot-Nederlandsch Studentencongres', Nieuwe Leidsche Courant, 22 april 1925. Zie ook: 'Het tiende groot Nederlandsch studentencongres', Leidsche Courant, 21 april 1925.

40 H. Kramers e.a., Het Leidse Volkshuis: Geschiedenis van een stichting sociaal-kultureel werk (Leiden, 1982); J.P.M. Roozen, 'Leidse bibliotheken rond de eeuwwisseling', Leids Jaarboekje (Leiden 1983) 149166; W. Otterspeer, Van allegorisch naar echt-historisch en terug. De geschiedenis van de Leidse Studenten maskerade (Leiden 1980).

41 F. de Raat, 'Leiden. De ongenadige metamorfose van Leiden', NRC Handelsblad, 21 december 1996. 
Pas in de jaren zestig zouden de sociale verhoudingen in Leiden sterk opgeschud worden, door het opgroeien van de babyboomers, de sterke groei van de studentenpopulatie en het verdwijnen van de industrie. Het gebruik van het hete muntjes strooien was toen al lang verdwenen, maar het verhaal erover werd juist prominenter. Nadat er in de jaren veertig en vijftig geen melding werd gemaakt over het strooien van gloeiende centen in Leidse kranten, nam het aantal besprekingen in de jaren zestig, zeventig en tachtig toe.

\section{Jaren zestig-tachtig: studentenrevolte en stadsvernieuwing}

In de jaren zestig werd het verhaal over de hete munten opnieuw intensief besproken. Daarbij bleek de gespannen verhouding tussen verhaal en werkelijkheid. Nadat het strooien van munten in 196o door de drie Leidse kranten in algemene zin was aangehaald, besloot een medicijnenstudent in 1961 de proef op de som te wagen. Hij gooide verhitte stuivers uit het raam van zijn studentenkamer, waarop kinderen hun handen brandden. De student werd aangehouden en voor de rechter gedaagd, van wie hij een boete van dertig gulden kreeg. De zaak kreeg enige aandacht in de Leidse pers, ${ }^{42}$ maar in latere verwijzingen naar het munten strooien werd nooit meer verwezen naar dit daadwerkelijke incident.

Hoewel het strooien van hete centen dus geen wijdverbreid gebruik was in Leiden, werd het wel als zodanig aangehaald; als ideale illustratie van een veel breder probleem. Toen de studente Ine Leermakers eind jaren zestig naar Leiden kwam, ging het verhaal nog altijd rond, met een duidelijke boodschap: "De "corpsballen" waren niet geliefd onder de Leidse bevolking. Ik had verhalen gehoord [sic], dat ze vanaf hun balkon gloeiende munten op straat gooiden voor het Leidse volk, dat zich dan de handen brandde. ${ }^{43}$ Volgens sommigen liet het incident zien dat er in de stedelijke verhoudingen nog weinig veranderd was. Toen het gebouw van Minerva in 1959 tot de grond toe afbrandde, moest 'menige voorbijganger ... wel gniffelen', want 'gewone Leienaars en Minervanen, dat was water en vuur'.44

Maar het verhaal haakte ook in op ontwikkelingen binnen de Leidse studentenbeweging. Deze was halverwege de jaren zestig opgekomen en had in 1969 haar hoogtepunt bereikt met de bezetting van het Aca-

42 'Flinke boete voor rare streek', Leidsche Courant, 24 januari 1961; 'Rare studentenstreek flink beboet', Nieuwe Leidsche Courant, 24 januari 1961; 'Studentenstreek flink beboet', Leidsch Dagblad, 25 januari 1961.

43 I. Leermakers, Leidse Stag Drukkerij. Coöperatieve Vereniging UA (Leiden 2015), 16.

44 'Feestend Minerva en het klootjesvolk', Leidsch Dagblad, 3 december 2013. 
demiegebouw. Toen de regering daarop reageerde met bestuurshervormingen, ontstonden er tegenstellingen onder de studenten: moest men zich richten op de verdere democratisering van de universiteit of juist de blik verruimen en zich verbinden met de strijd van de Leidse stadsbevolking? Het conflict leidde onder andere tot de ondergang van de Algemene Leidse Studentenvereniging (ALSV) en de vorming van een afdeling van de Kommunistische Eenheidsbeweging Nederland (voorloper van de SP) in Leiden. ${ }^{45}$

In het zelfbeeld van maatschappelijk geëngageerde studenten - ook in andere studentensteden - speelde het verhaal over de munten een belangrijke rol, zoals bijvoorbeeld blijkt uit een herinnering van de journalist Walter van der Kooi, die in zijn studententijd het (Amsterdamse) studentencorps haatte. Hij weigerde in die periode zelfs een glas bier van een medestudent uit een villa in Amsterdam-Zuid, want: 'Ik kende het verhaal over, bij wijze van spreken, zijn grootvader die gloeiende centen uit het raam van de sociëteit gooide waar door kindertjes uit De Pijp, bij wijze van spreken mijn grootvader, om gevochten werd'. ${ }^{46}$

Het verhaal paste goed in een populaire redenering, volgens welke corpsstudenten niet alleen asociaal, maar ook boven de wet verheven waren. Illustratief daarvoor was niet alleen het verhaal over het munten gooien, maar ook de zogenaamde roetkap-affaire van 1965; een tragisch incident bij de ontgroeningen in het Utrechts Studenten Corps (USC), waarbij een aanstaand lid een roetkap over zijn hoofd geplaatst kreeg en stikte. De daders werden aangeklaagd, maar kregen uiteindelijk zeer lage straffen opgelegd. Omdat de autoriteiten in dezelfde periode hard optraden tegen Provo's en andere activisten was het oordeel controversieel. ${ }^{47}$ Terwijl in de praktijk het werpen van munten leidde tot politie-ingrijpen, speelde de verhevenheid boven de wet toch een belangrijke rol in het verhaal dat erover verteld werd.

In de discussies over de rol van de student die in de jaren zestig gevoerd werden, liepen lokale en landelijke ontwikkelingen dus door elkaar heen. Toch kreeg het verhaal in de periode daarop een sterk lokale dimensie, omdat de stedelijke verhoudingen in Leiden in de jaren zestig, zeventig en tachtig stevig op de proef werden gesteld. Leiden was van oudsher een arme industriestad, die gekenmerkt werd door een scherpe

45 S. Slangen, “'Ouwe lullen motten weg”. Studentenprotest, acties en het alternatieve circuit in Leiden in de late jaren zestig', in: D. Wintgens Hötte (ed.), De jaren zestig. Actie, kunst en cultuur in Leiden (Leiden 1989) 29-51.

46 W. van der Kooi, 'Vernieling', Groene Amsterdammer, 16 februari 1994.

47 J. Bloemkolk, ‘De jongen die stierf onder de roetkap', Het Parool, 4 december 1998. 
tweedeling tussen de arbeidersbevolking en de 'universitaire elite' (studenten en professoren).$^{48}$

In de jaren zestig golden de lonen in Leiden nog altijd als de laagste van Nederland, terwijl Het Vaderland de stad uitriep tot 'tweede landskampioen krotten'. ${ }^{49}$ Leiden raakte in de daaropvolgende periode in een crisis. De stedelijke industrie verdween, waardoor de werkloosheid steeg tot vijftien procent, beduidend hoger dan het landelijk gemiddelde. De stedelijke financiën kwamen in zwaar weer en de stad werd onder curatele gesteld. De stedelijke vernieuwing verliep traag en moeizaam. Een onderzoeker stelde in 1976: 'Alle gemeenten hebben problemen, maar Leiden heeft ze allemaal. ${ }^{50}$ Pas in de jaren negentig werd Leiden wederom een welvarende stad, vooral door de opkomst van biofarmaceutische industrie..$^{51}$ De universiteit werd steeds belangrijker als werkgever en pijler van de stedelijke economie..$^{2}$ Terwijl de stad middels een moeizaam proces ingrijpend transformeerde, veranderden de rol van de universiteit en de student in de stad evenzeer.

Zowel studenten als 'gewone' Leidenaren reflecteerden op deze ontwikkelingen. Het verhaal over de gloeiende munten werd daarbij inzet van een discussie over de positie van de stad en van de student. Zo haalde de Zangeres zonder Naam in 1969 het verhaal van de gloeiende munten aan om het oude Leiden te beschrijven. Zij vervolgde: 'Als ik Leiden nu bezoek, vind ik de stad enorm vooruitgegaan, dynamischer, waardiger, kortom een goede stad om in te leven. Veel beter dan in de tijd toen ik jong was. ${ }^{53}$ Deze redenering bleef tot in de jaren tachtig populair. Zo vertelde een oudere bewoner van Leiden Noord in 1981 aan Rudie Kagie, nadat hij over de 'lamstralen' had verteld die gloeiende munten uit hun koetsjes hadden gegooid: 'Zulke studenten heb je gelukkig niet meer. De studenten die we nu zien in de wijk zijn aardige jonge mensen. Ze helpen volwassenen met de huiswerkcursus. ${ }^{54}$ Weer een andere 'gewone' Leidenaar, een trainer bij de studentenroeivereniging Njord, was zo te spreken over de houding van de studenten dat hij het verhaal geheel in

\footnotetext{
48 F. Boersma, 'Economische en sociale verhoudingen. Breuk met het verleden', in:Van Maanen, Leiden, 59-99.

49 C. Smit, 'Rondkomen in Leiden, 1850-200o', Jaarboek Dirk van Eck (Leiden 2001) 105-152, 124; Idem, Strijd om kwaliteit. De geschiedenis van de volkshuisvesting in de regio Leiden (Leiden 2006) 127130; Idem, 'Een troosteloze aanblik. Leiden in de jaren zestig', in: Wintgens Hötte, De jaren zestig, 17-28.

5o Idem, Strijd om kwaliteit, 176-178.

51 Boersma, 'Economische en sociale verhoudingen'.

52 W. Otterspeer, 'De Universiteit', in: Van Maanen, Leiden, 190-205.

53 'Wat ik van Leiden vind', Leidsche Courant, 1 november 1969.

54 R. Kagie, Leiden Noord. Beeld van een wijk (Rijswijk 1981) 6.
} 
twijfel trok: 'Want wie dat praatje ooit in de wereld heeft gebracht ... 55 Ook de redeneringen van de corpsstudenten zelf pasten binnen dit format. In 1989 gaven twee bestuursleden van Minerva 'volmondig' toe dat hun voorgangers gloeiendhete centen van het balkon van de sociëteit hadden gegooid. Maar, zo stelden ze: 'Nu is het anders, de studenten moeten wel degelijk om zich heen kijken en zich aanpassen. ${ }^{56}$ In 1991 stelde de voorzitter van Minerva dat het gedaan was met de 'misstanden van vroeger'. Inmiddels hadden de corpsstudenten zich ontwikkeld tot beschaafde en maatschappelijk bewuste burgers: 'Binnen Minerva is er nu zelfs een divisie [sic] die zich wijdt aan burgerzaken'. ${ }^{57}$

Tegelijkertijd werd deze claim regelmatig ter discussie gesteld. In 1981 haalde de Leidse Studentenbond (LSB) het centen strooien van vroeger aan, om vervolgens te stellen dat er sindsdien maar weinig veranderd was. In een brochure werd er een continuïteit geschapen tussen de elitaire, reactionaire studentenclubs uit de negentiende eeuw en de corpsstudenten uit de jaren zeventig en tachtig. In een van de bijdragen werd een lange reeks van incidenten opgesomd uit de afgelopen tweehonderd jaar, waarin Leidse corpsstudenten het de Leidse bevolking zuur hadden gemaakt. Een van deze incidenten behelsde het feit 'dat studenten gloeiend hete centen naar het volk gooiden op 3 oktober', wat volgens de auteur 'waarschijnlijk wel bekend' was. De opsomming eindigde met een korte uitweiding over incidenten in het jaar 1972, onder de titel 'nog steeds dezelfden'. ${ }^{5}$ Daarmee werd expliciet gemaakt dat volgens de auteur de houding van de Leidse corpsstudent in tweehonderd jaar ongewijzigd was gebleven. In 1991 was de positie van de student in de stad zelfs thema van een debatavond in het poppodium en jongerencentrum LVC. Daar stelde een man uit het publiek over de Minervanen: 'Bah, jullie zitten op een ivoren toren en werpen centen naar het volk. Maar we leven in een verzorgingsstaat en er is dus niemand afhankelijk van liefdadigheid.59

De discussie in het LVC ging niet over de vraag of studenten wel of niet met gloeiende munten hadden gestrooid. Het ging om de exemplarische waarde van de anekdote: had de corpsstudent zich inmiddels ontwikkeld tot een maatschappelijk bewuste burger, of niet? Had de Leidse burgerbevolking zich ontworsteld aan onmondigheid en armoede,

55 'Leeuw van Njord met pensioen', Leidsch Dagblad, 5 maart 198 o.

56 'Minerva tapt uit een ander vaatje', Leidsche Courant, 1 juli 1989. Zie ook: 'We willen het lustrum niet voor onszelf houden', Leidsch Dagblad, 1 maart 1989.

57 'Oeverloos', De Peueraar, februari 1991; 'Marsmannetjes', Leidsch Dagblad, 1 o januari 1991.

58 Leidse Studentenbond, Nog meer snikken en glimlachjes ... Over de 'Leidsche Student'(Leiden 1980) 9.

59 'Oeverloos', De Peueraar, februari 1991; 'Marsmannetjes', Leidsch Dagblad, 1 o januari 1991. 
of niet? Deze twee vragen stonden telkens weer ter discussie wanneer het verhaal over de gloeiende munten aangehaald werd. Discussies over de Leidse student raakten zo onlosmakelijk verbonden met discussies over de staat van de stad. Daarbij gebruikte een groep het voorbeeld van munten strooien om te laten zien dat de situatie sindsdien sterk verbeterd was, terwijl de tweede groep juist benadrukte dat armoede nog altijd een groot probleem was in de stad.

\section{Conclusie}

Het gebruik om (gloeiende) munten te strooien heeft zijn wortels in de folklore; het was niet typisch Leids en het was geen typische studentenstreek. Het gebruik wordt in Leiden echter wel zo herinnerd: als tekenend voor de Leidse identiteit. Deze specifieke herinnering aan het algemene gebruik heeft zich vooral ontwikkeld in de twintigste eeuw, toen het strooien van munten als gebruik vrijwel uitgestorven was. Hoe is deze ontwikkeling te verklaren?

In de eerste plaats ging de anekdote een centrale rol spelen in discussies over de rol van de student in de maatschappij. Deze discussies vonden al plaats voor de Tweede Wereldoorlog, maar begonnen pas echt in de jaren zestig van de vorige eeuw. Zowel voor Leidenaren als voor Leidse studenten was het een belangrijk thema en het verhaal over de gloeiende munten vormde bij discussies een vast referentiepunt. Toch was deze discussie niet typisch Leids - ze vond ook plaats in andere studentensteden. Het verhaal werd pas echt een Leidse toop in de jaren zestig, zeventig en tachtig, omdat het toen een tweede rol ging vervullen. In deze periode veranderde Leiden van een arme, industriële, verkrotte en verdeelde stad in een welvarende stad. De overgang was moeizaam en langdurig en ging gepaard met hoge werkloosheid en sociale spanningen. Stadshistoricus Cor Smit noemt de jaren zeventig en tachtig daarom een 'donkere periode in de sociale geschiedenis van Leiden. ${ }^{60}$ Juist in deze periode werd het verhaal over de munten inzet van discussies over de vraag of Leiden zijn achtergestelde positie aan het overwinnen was of niet. Volgens sommigen toonde het verhaal dat Leiden inmiddels grondig was veranderd, terwijl anderen juist continuïteit zagen. Toen het overgangsproces halverwege de jaren negentig was voltooid, begon het verhaal in Lei-

6o Smit, Strijd om kwaliteit, 176-177. 
den aan betekenis en zeggingskracht te verliezen. Desondanks wordt het gebruik nog veelvuldig aangehaald, niet zozeer in kranten, maar wel op bijvoorbeeld weblogs.

Ons onderzoek illustreert hoe collectief geheugen en stedelijke identiteit met elkaar verbonden zijn en elkaar bepalen. Naarmate de stad verandert, veranderen ook de verhalen over en de herinneringen aan de stad. In de mate dat kranten informatie geven over informele stadsverhalen, bieden ze ook de gelegenheid om de verandering van deze verhalen te reconstrueren en te verklaren. Het gaat in ons onderzoek niet zozeer over het waarheidsgehalte van het verhaal, maar over de veranderende betekenis die het verhaal door de tijd heen werd toegekend. Kranten bieden de mogelijkheid om de ontwikkeling daarvan te onderzoeken, omdat het verhaal daarin vaak wordt aangehaald: in opmerkingen van journalisten, in interviews met 'gewone' Leidenaren en in terugblikken. Het verhaal over de gloeiende munten laat zien hoe de reflecties op de stedelijke identiteit veranderden, omdat verschillende groepen naar het gebruik verwezen en hier door de tijd heen verschillende betekenissen aan gaven.

Ons onderzoek bevat een aantal aanknopingspunten voor verder onderzoek. In de eerste plaats is het interessant om te weten te komen of het verhaal nu nog leeft onder Leidenaren en Leidse studenten. Middels enquêtes zou zo'n onderzoek kwantitatief opgezet kunnen worden. Helaas zijn de mogelijkheden om zulk onderzoek ook een historische dimensie te geven beperkt. Een andere mogelijkheid zou kunnen zijn om te onderzoeken in hoeverre het verhaal over de gloeiende munten verbonden was met - en versterkt werd door - andere lokale verhalen zoals de anekdote dat de Leidse bevolking - ondanks de grote studentenpopulatie - gemiddeld het laagste IQ had van Nederland. Dit verhaal deed vooral opgeld in de jaren zeventig en tachtig en thematiseert op een gelijkaardige manier de positie van de student in de stad en de al dan niet achtergestelde positie van Leiden.

Het verhaal over gloeiende munten wordt nog altijd verteld. Sterker nog, de praktijk van het munten strooien bestaat nog altijd. In maart 2017 kwamen PSV-supporters in het nieuws omdat zij in Madrid Sinti en Roma naar munten lieten grabbelen. ${ }^{61}$ Van een typisch Leids verhaal over het munten strooien is echter geen sprake meer. Wanneer het gebruik genoemd wordt in verband met studen- 
ten, vindt dat plaats in een meer algemene context over ontgroeningsexcessen, bijvoorbeeld bij het Groningse Vindicat. Het Dagblad van het Noorden stelde in dat verband: 'Verhalen over Vindicaters die gloeiend hete muntjes wierpen naar de arme burgers op straat en over piano's die van het balkon werden gegooid, gaan nog altijd rond. ${ }^{62}$ Onze stelling dat het verhaal sinds de jaren negentig aan zeggingskracht heeft verloren lijkt ook te worden bevestigd door gesprekken met studenten, die het verhaal lang niet altijd kennen.

Toch bezit het verhaal over de studenten en hun hete centen nog steeds een zeker subversief potentieel. Het ontbreekt in de recente geschiedboeken van het studentencorps en in het stripboek De ziel van Leiden (2017). ${ }^{63}$ De Leidse City Marketing roept graag de glorieuze academische geschiedenis van de stad in herinnering, maar gaat liever voorbij aan de klassentegenstellingen die daar een deel van waren, inclusief het verhaal over de hete centen. Het verhaal is niet overal welkom, omdat het een beeld oproept van een stad waarmee een steeds kleinere groep zich wil identificeren.

\section{Over de auteurs}

Peter Burger (1961) is a University Lecturer at the Department of Journalism and New Media at Leiden University. He applies rhetorical perspectives to journalism, narrative folklore, and social media discourse. Recent publications include: P. Burger, Monsterlijke verhalen. Misdaadsagen in het nieuws en op webforums als retorische constructies (Den Haag: Boom Lemma, 2014) and P. Burger, 'Komkommers, zeeslangen, canards en faits divers. Nederlandse kranten (1850-1950) als sagenmedium.' Volkskunde 3 (2017) 291-318.

E-mail: p.burger@hum.leidenuniv.nl

Bart van der Steen (1983) is a University Lecturer in modern history at Leiden University. His research focuses on labour and social movements in Europe from the late nineteenth century to the present. Recent publications include: K. Andresen and B. van der Steen, A European Youth Revolt. European Perspectives on Youth Protest and Social Movements in the 1980 (Houndmills: Palgrave MacMillan, 2016) and B. van der Steen, L. van Hoogenhuijze and A. Katzeff, The City is Ours. Squatting and Autonomous Movements in Europe, 1980-2014 (Oakland: PM Press, 2014).

E-mail: b.s.van.der.steen@hum.leidenuniv.nl

62 M. Borst, 'Vindicat staat voor vriendschap, eer en beschaving', Dagbladvan het Noorden, 1 oktober 2016. 63 De zielvan Leiden. 